UDC 538.913

\title{
ANALYSIS OF STATISTICAL CHARACTERISTICS OF QUASI- BREATHER IN MONOATOMIC FCC METALS Au, Cu, Ni, Pd AND Pt
}

\author{
(C) 2018 A. M. Eremin ${ }^{1}$, P. V. Zakharov ${ }^{1}$, M. D. Starostenkov ${ }^{2}$, A. S. Vdovin ${ }^{1}$ \\ ${ }^{1}$ Shukshin Altai State Humanities Pedagogical University, 53, Korolenko str., 659333 Altai region, Biysk, Russia \\ ${ }^{2}$ Polzunov Altai State Technical University, 46, Lenina av., 656038 Altai region, Barnaul, Russia \\ e-mail:eam77@yandex.ru
}

Received 08.08.2018

\begin{abstract}
The molecular dynamics method is used to calculate and analyze the statistical characteristics of a quasi-breather with a hard type of nonlinearity in monoatomic FCC metals, for example, $\mathrm{Cu}$, $\mathrm{Au}, \mathrm{Pt}, \mathrm{Ni}$ and Pd. Within the framework of this model, the following statistical characteristics and dependencies were calculated for quasi-breathers: a grouped statistical series of absolute and relative frequencies, a polygon of absolute and relative frequencies, a histogram of relative frequencies, an empirical distribution function, an estimate of the mathematical expectation and variance of the original sample. The densities of phonon states are calculated for all crystals. Statistics allow you to understand the causes of the destruction of breathers and more fully describe the process of their dissipation of energy.
\end{abstract}

Keywords: crystal, quasi-breather, discrete breather, nonlinear dynamics, soliton, molecular dynamics.

DOI: https://doi.org/10.17308/kcmf.2018.20/628

\section{INTRODUCTION}

One of the most interesting and important objects of nonlinear physics for practical application are solitontype waves (solitary waves) [1-2]. Despite the fact that solitons are known to science for more than 180 years, they have been little studied in many fields of knowledge. So, recently interest to discrete nonlinear systems in which the existence of dynamic solitons is possible increases. An example of a dynamic soliton can serve as discrete breathers (DB) - localized in space and periodic in time high-amplitude excitations in nonlinear discrete structures with translational symmetry [3].

It is assumed that the DBs participate in various solid-state processes. In particular, DB can increase the catalytic properties of nanoparticles with a disordered structure, lead to radiation-stimulated growth of pores in metals, contribute to diffusion, transport electric charge, lead to annealing of defects, reduce the energy barrier of chemical reactions in crystalline solids, etc. [4-5].

Discrete breathers can be divided into two types according to the nature of their frequency dependence on the amplitude [6]. In discrete breathers of a soft type, the frequency decreases with increasing amplitude (such discrete breathers can exist only in crystals having a gap in the phonon spectrum: their frequency lies in the slit of the phonon spectrum and therefore they are called slotted), and in discrete hard type breather the opposite occurs (they can have frequencies, both in the gap and above the phonon spectrum). Discrete breathers with a soft type of nonlinearity can be excited in biatomic crystals, for example, in $\mathrm{NaCl}$ [6], $\mathrm{Pt}_{3} \mathrm{Al}$ [714], as well as in graphene and graphane [15]. Breather with a hard type of nonlinearity exist in pure metals with FCC-, BCC-, and HCP-structures. For pure metals or ordered alloys with a small difference in mass, the conditions for excitation of a DB with a hard type of nonlinearity are more specific than when exciting slit DBs with a soft type of nonlinearity.

It is necessary to make a terminological reservation. In mathematical physics, DB means strictly periodic, non-local oscillations localized in space, continuous in time, at one frequency, but in real systems where the presence of all possible perturbations is inevitable, one should consider quasi-breathers having a non-strict periodicity of oscillations with frequencies in a certain range and finite life time [16]. Unlike idealized DB, quasi-breathers have an infinite, but rather long, lifetime. Quasi-breathers arise in the presence of small deviations from accurate breather solutions in the multidimensional space of all possible initial conditions in the solution of 
the Cauchy problem for nonlinear differential equations, since in this case there is no complete suppression of the contributions from oscillations of peripheral particles with their own frequencies. Thus, weakening of the leading vibration of the breather core (in our calculations, the core of a symmetric breather forms one particle, and in the case of an antisymmetric breather, two of its central particles) leads to the presence of additional vibration frequencies in the breather solution. These small contributions can be found in the vibrations of all quasi-breather particles, in particular, central ones. If the frequencies of oscillations of all quasi-breather particles computed at a certain time interval near $t=t_{k}$ are determined sufficiently accurately, then they will not be strictly identical. Further, the terms breather, discrete breather and quasi-breather will be used as synonyms.

The monoatomic FCC metals $\mathrm{Cu}, \mathrm{Au}, \mathrm{Pt}, \mathrm{Ni}$ and $\mathrm{Pd}$ are considered in this paper. The main goal of the paper is to calculate and analyze the statistical characteristics of quasi-breathers with a hard type of nonlinearity in the specified materials. The data obtained will make it possible to characterize the evolution of a quasibreather over time.

\section{COMPUTER MODEL AND DESCRIPTION OF THE EXPERIMENT}

The models we are considering are bulk crystals containing $10^{5}$ to $3 \cdot 10^{5}$ particles interacting via a potential obtained by the immersed atom method (EAM potential). The simulation was carried out using the LAMMPS package [17].

In computational chemistry, the immersed atom model is used to approximate the interaction energy between two atoms, taking into account the presence of neighboring atoms. The choice of the potential and the validity of its use for a specific task is an important stage in the modeling.

The total energy $E$ of the crystal can be expressed as $E=\frac{1}{2} \sum_{i, j, i \neq j} \varphi_{i j}\left(r_{i j}\right)+\sum_{i} F_{i}\left(\rho_{i}\right)$, where $\varphi_{i j}$ represents the pair interaction energy of atoms $i$ and $j$, located at a distance $r_{i j}$ from each other, and $F_{i}$ is the embedding energy associated with placing the atom $i$ in a location with electron density $\rho_{i}$. The electron density takes into account the position of the surrounding atoms and can be calculated from the formula $\rho_{i}=\sum_{j, j \neq i} f_{j}\left(r_{i j}\right)$, where $f_{j}\left(r_{i j}\right)$ is the electron density at the site of the atom $\mathrm{i}$ located at a distance $r_{i j}$ from the atom $j$.

The EAM potential of a pure element is determined by three functions: the pair energy $\varphi$, the electron density $\rho$, and the embedding energy $F$. For the alloy, the EAM potential contains not only the three functions $\varphi, \rho$, and $F$ for each of the constituent elements, but also the pair energies $\varphi_{\mathrm{ab}}$ between the different elements $a$ and $b$ $(a \neq b)$. As a result, the functions $\varphi, \rho$, and $F$ calculated for pure metals can not be directly applied to the alloy or multilayer systems. Nevertheless, the procedure for generalizing EAM potentials and their trimming distance by normalizing EAM potentials and introducing an alloy model was proposed by the author of [18]. This procedure enables the construction of EAM potentials of alloys from EAM-potentials for individual elements. Such potentials of alloys were used in molecular modeling and gave good results in experiments [18]; we used this potential for the CuAu crystal [19].

The main factor determining the lifetime of the DB in real crystals is the remoteness of its frequency from the frequencies of the phonon spectrum, and therefore dispersion curves and phonon-state densities for the crystals under study were calculated (see Fig. 1). The calculations used the software package LAMMPS, which includes the procedures necessary for these purposes, based on the Fourier transform of the autocorrelation functions of atomic displacements versus time.

Next, the statistical characteristics of DB in monoatomic crystals $\mathrm{Cu}, \mathrm{Au}, \mathrm{Pt}, \mathrm{Ni}$ and $\mathrm{Pd}$ will be calculated and analyzed.

\section{RESULTS AND DISCUSSIONS}

The main statistical characteristics of the quasibreather are the standard deviation $\eta\left(t_{k}\right)$ (Fig. 2) and the mean value of the frequency $\varpi$ of atomic vibrations, where $t_{\mathrm{k}}$ is the quasi-breather lifetime [20-21]:

$$
\begin{gathered}
\eta\left(t_{k}\right)=\sqrt{\frac{\sum_{i=1}^{N}\left(\omega_{i}\left(t_{k}\right)-\bar{\omega}\left(t_{k}\right)\right)^{2}}{N(N-1)} .} \\
\bar{\omega}\left(t_{k}\right)=\frac{1}{N} \sum_{i=1}^{N} \omega_{i}\left(t_{k}\right),
\end{gathered}
$$

The lifetime of these quasi-breathers was divided into five equal parts. Thus, five points were obtained for analyzing the statistical characteristics of breathers (see Fig. 2). That is, there was a sample of five elements frequencies of quasi-breathers, see Table 1.

Next, we constructed the statistical series of absolute frequencies for this sample, i.e. the sequence of pairs of numbers $\left(\omega_{1}{ }^{*}, n_{1}{ }^{*}\right),\left(\omega_{2}{ }^{*}, n_{2}{ }^{*}\right), \ldots,\left(\omega_{m}{ }^{*}, n_{m}{ }^{*}\right)$, where $\omega_{k}^{*}$ is the center of the $k$-interval of the grouping and $n_{1}^{*}$ is the number of sampling elements in $k$-interval. The numbers. $n_{k}{ }^{*}(k=1, \ldots, m)$ are called absolute frequencies. We find the minimum and maximum sample elements, they correspond to 

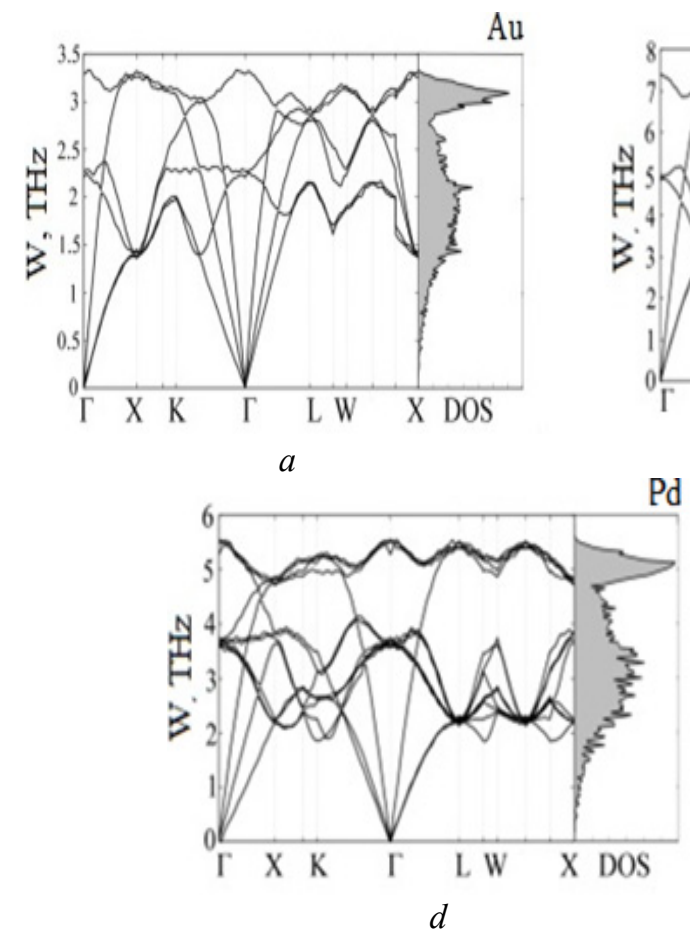
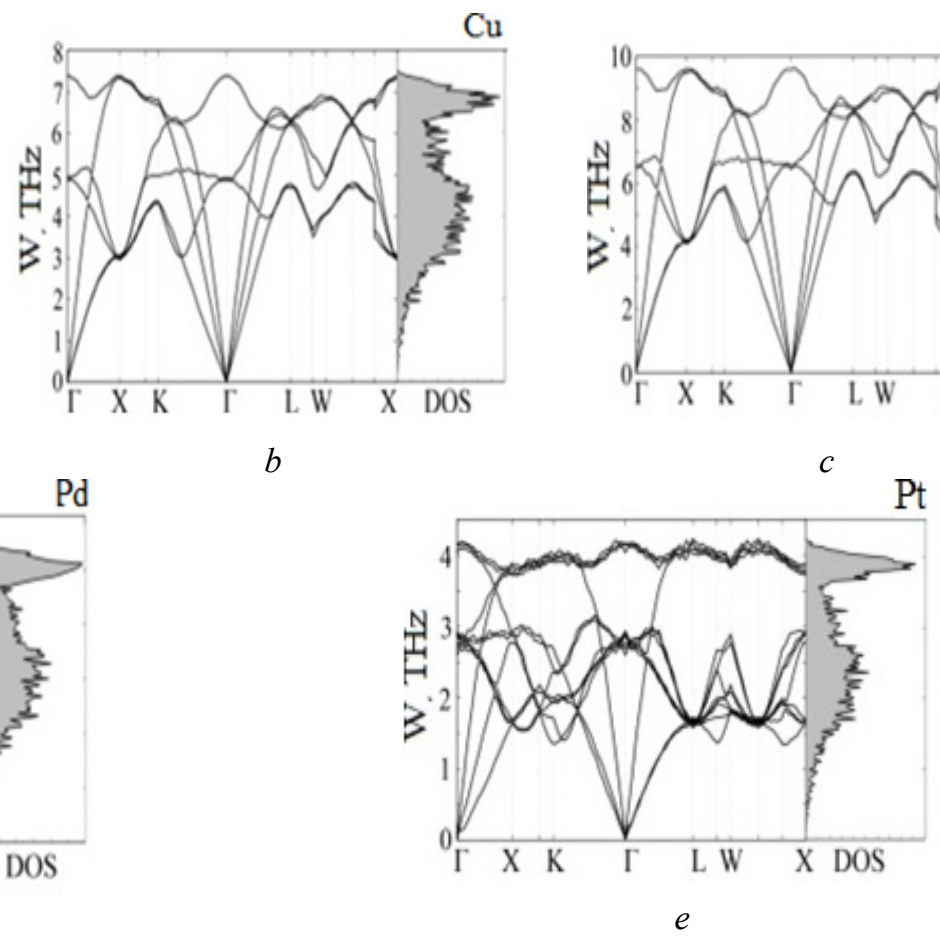

Fig. 1. Dispersion curves and densities of phonon states for metals: $a-\mathrm{Au}, b-\mathrm{Cu}, c-\mathrm{Ni}, d-\mathrm{Pd}, e-\mathrm{Pt}$

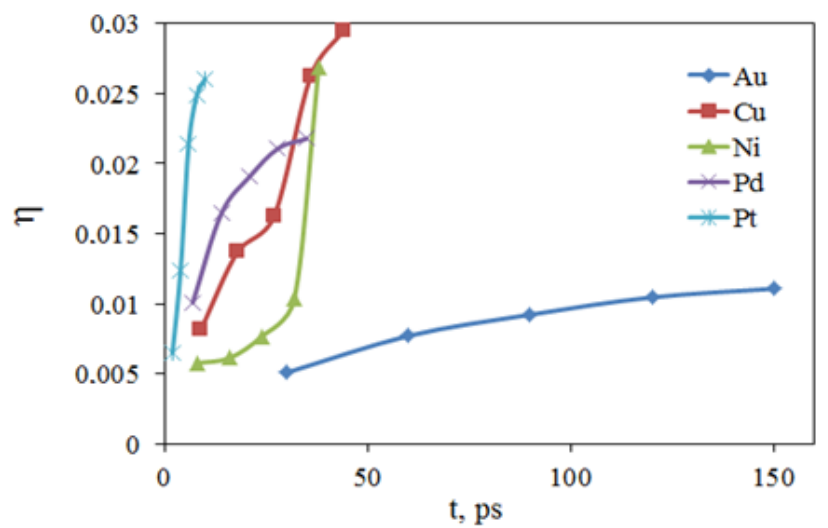

Fig. 2. Dependence of the root-mean-square deviation of vibration frequencies of quasi-breather atoms on their lifetime for $\mathrm{Cu}, \mathrm{Au}, \mathrm{Pt}, \mathrm{Ni}$, and $\mathrm{Pd}$

Table 1. Frequency sampling of a quasi-breather

\begin{tabular}{|c|c|c|c|c|c|}
\hline Model & $\varpi_{1}, \mathrm{THz}$ & $\varpi_{2}, \mathrm{THz}$ & $\varpi_{3}, \mathrm{THz}$ & $\varpi_{4}, \mathrm{THz}$ & $\varpi_{5}, \mathrm{THz}$ \\
\hline $\mathrm{Cu}$ & 8.18301 & 7.87534 & 7.72063 & 7.42053 & 7.33631 \\
\hline $\mathrm{Au}$ & 3.56532 & 3.51414 & 3.48136 & 3.42447 & 3.37433 \\
\hline $\mathrm{Pt}$ & 4.47930 & 4.37063 & 4.22345 & 4.12226 & 4.04060 \\
\hline $\mathrm{Ni}$ & 10.52174 & 10.33132 & 10.16977 & 9.99958 & 9.85306 \\
\hline $\mathrm{Pd}$ & 5.85093 & 5.69786 & 5.61925 & 5.49998 & 5.40357 \\
\hline
\end{tabular}

the extreme values for each model in Table 1. Find the length of the grouping interval by the formula:

$$
h=\left(\omega_{\max }-\omega_{\min }\right) / m \text {. }
$$

We find the right boundaries of the grouping intervals:

$$
\omega_{k}=\omega_{\min }+k h(\kappa=1, \ldots, 5) \text {. }
$$

We find the centers $\omega^{*}{ }_{k}$ intervals of the grouping by the formula:

$$
\omega_{k}^{*}=\omega_{k}-h / 2(\kappa=1, \ldots, 5) .
$$

For each grouping interval $\left(\omega_{k-1}, \omega_{k}\right)$ we find the number $n_{k}{ }^{*}$ of sample elements that fall in this interval. It is important that each sample element is assigned to one and only to one interval, and if the value of the element falls on the interval boundary, then we will refer it to the interval with the lowest number. The minimum element is always referred to the first interval, the maximum to the last. The results are shown in Table 2.

We build a grouped statistical series of relative frequencies, which is a sequence of pairs of numbers $\left(\omega_{1}{ }^{*}, n_{1}{ }^{*} / n\right),\left(\omega_{2}{ }^{*}, n_{2}{ }^{*} / n\right), \ldots,\left(\omega_{m}{ }^{*}, n_{m}{ }^{*} / n\right)$, where $n_{k}{ }^{*} / n$ are the relative frequencies and $\mathrm{n}$ is the sample size (see Table 3).

Based on Table 3, we construct the relative frequency polygons for each of the crystal models (see Fig. 3).

To complete the statistical picture of the cha-racteristics of quasi-breathers, we estimate the mathematical expectation and variance, and also construct empirical distribution functions.

Estimate of the mathematical expectation (sample mean) of a grouped sample is calculated using the formula: 
Table 2. Supporting table of statistical data

\begin{tabular}{|c|c|c|c|}
\hline Model & $\begin{array}{l}\text { Number of } \\
\text { interval } k\end{array}$ & $\begin{array}{c}\text { Center of interval } \\
\omega_{k}{ }^{*}, \mathrm{THz}\end{array}$ & $\begin{array}{c}\text { Limits of interval, } \\
\text { THz }\end{array}$ \\
\hline \multirow{5}{*}{$\mathrm{Cu}$} & 1 & 7.42098 & $7.33631 \ldots 7.50565$ \\
\hline & 2 & 7.59032 & $7.50565 \ldots 7.67499$ \\
\hline & 3 & 7.75966 & $7.67499 \ldots 7.84433$ \\
\hline & 4 & 7.92900 & $7.84433 \ldots 8.01367$ \\
\hline & 5 & 8.09834 & $8.01367 \ldots 8.18301$ \\
\hline \multirow{5}{*}{$\mathrm{Au}$} & 1 & 3.39343 & $3.37433 \ldots 3.41253$ \\
\hline & 2 & 3.43162 & $3.41253 \ldots 3.45072$ \\
\hline & 3 & 3.46982 & $3.45072 \ldots .3 .48892$ \\
\hline & 4 & 3.50802 & $3.48892 \ldots 3.52712$ \\
\hline & 5 & 3.54622 & $3.52712 \ldots 3.56532$ \\
\hline \multirow{5}{*}{$\mathrm{Pt}$} & 1 & 4.08447 & $4.04060 \ldots 4.12834$ \\
\hline & 2 & 4.17221 & $4.12834 \ldots 4.21608$ \\
\hline & 3 & 4.25996 & $4.21608 \ldots 4.30383$ \\
\hline & 4 & 4.34770 & $4.30383 \ldots 4.39157$ \\
\hline & 5 & 4.43544 & $4.39157 \ldots 4.47931$ \\
\hline \multirow{5}{*}{$\mathrm{Ni}$} & 1 & 9.91993 & $9.85306 \ldots 9.98680$ \\
\hline & 2 & 10.05366 & $9.98680 \ldots 10.12053$ \\
\hline & 3 & 10.18740 & $10.12053 \ldots 10.25427$ \\
\hline & 4 & 10.32114 & $10.25427 \ldots 10.38800$ \\
\hline & 5 & 10.45487 & $10.38800 \ldots 10.52174$ \\
\hline \multirow{5}{*}{$\mathrm{Pd}$} & 1 & 5.44831 & $5.40357 \ldots 5.49305$ \\
\hline & 2 & 5.53778 & $5.49305 \ldots .5 .58252$ \\
\hline & 3 & 5.62725 & $5.58252 \ldots .5 .67199$ \\
\hline & 4 & 5.71673 & $5.67199 \ldots 5.76146$ \\
\hline & 5 & 5.80620 & $5.76146 \ldots .5 .85093$ \\
\hline
\end{tabular}

Table 3. Grouped statistical series of relative frequencies

\begin{tabular}{|c|c|c|c|c|c|c|}
\hline \multirow{2}{*}{$\mathrm{Cu}$} & $\omega_{k}{ }^{*}, \mathrm{THz}$ & 7.42098 & 7.59032 & 7.75966 & 7.92900 & 8.09834 \\
\cline { 2 - 7 } & $n_{k}{ }^{*} / n$ & 0.40000 & 0.00000 & 0.20000 & 0.20000 & 0.20000 \\
\hline \multirow{3}{*}{$\mathrm{Au}$} & $\omega_{k}{ }^{*}, \mathrm{THz}$ & 3.39343 & 3.43162 & 3.46982 & 3.50802 & 3.54622 \\
\cline { 2 - 7 } & $n_{k}{ }^{*} / n$ & 0.20000 & 0.20000 & 0.20000 & 0.20000 & 0.20000 \\
\hline \multirow{3}{*}{$P t$} & $\omega_{k}{ }^{*}, \mathrm{THz}$ & $\mathbf{4 . 0 8 4 4 7}$ & $\mathbf{4 . 1 7 2 2 1}$ & $\mathbf{4 . 2 5 9 9 6}$ & $\mathbf{4 . 3 4 7 7 0}$ & $\mathbf{4 . 4 3 5 4 4}$ \\
\cline { 2 - 7 } & $n_{k}{ }^{*} / n$ & $\mathbf{0 . 4 0 0 0 0}$ & $\mathbf{0 . 0 0 0 0 0}$ & $\mathbf{0 . 0 0 0 0 0}$ & $\mathbf{0 . 4 0 0 0 0}$ & $\mathbf{0 . 2 0 0 0 0}$ \\
\hline \multirow{3}{*}{$N i$} & $\omega_{k}{ }^{*}, \mathrm{THz}$ & 9.91993 & 10.05366 & 10.18740 & 10.32114 & 10.45487 \\
\cline { 2 - 7 } & $n_{k}{ }^{*} / n$ & $\mathbf{0 . 4 0 0 0 0}$ & $\mathbf{0 . 0 0 0 0 0}$ & $\mathbf{0 . 2 0 0 0 0}$ & $\mathbf{0 . 2 0 0 0 0}$ & $\mathbf{0 . 2 0 0 0 0}$ \\
\hline \multirow{2}{*}{$P d$} & $\omega_{k}{ }^{*}, \mathrm{THz}$ & $\mathbf{5 . 4 4 8 3 1}$ & $\mathbf{5 . 5 3 7 7 8}$ & $\mathbf{5 . 6 2 7 2 5}$ & $\mathbf{5 . 7 1 6 7 3}$ & $\mathbf{5 . 8 0 6 2 0}$ \\
\cline { 2 - 7 } & $n_{k}{ }^{*} / n$ & $\mathbf{0 . 2 0 0 0 0}$ & $\mathbf{0 . 0 0 0 0 0}$ & $\mathbf{0 . 4 0 0 0 0}$ & $\mathbf{0 . 2 0 0 0 0}$ & $\mathbf{0 . 2 0 0 0 0}$ \\
\hline
\end{tabular}

$$
M^{*}=\frac{1}{n} \sum_{k=1}^{n} \omega_{k} .
$$

The estimation of variance, not grouped sample, is carried out according to the formula:

$$
D^{*}=\frac{1}{n-1} \sum_{k=1}^{n}\left(\omega_{n}-M^{*}\right)^{2} .
$$

For the models we are considering, we have obtained the values given in Table 4.

For clarity, we construct empirical distribution functions $F(u)$ (see Fig. 4).
Table 4. Mathematical expectation and variance for model crystals

\begin{tabular}{|c|c|c|}
\hline Model & $M^{*}$ & $D^{*}$ \\
\hline $\mathrm{Cu}$ & 7.707168 & 0.118647 \\
\hline $\mathrm{Au}$ & 3.471924 & 0.005593 \\
\hline $\mathrm{Pt}$ & 4.269478 & 0.033139 \\
\hline $\mathrm{Ni}$ & 10.155099 & 0.080553 \\
\hline $\mathrm{Pd}$ & 5.634324 & 0.026402 \\
\hline
\end{tabular}


A. M. EREMIN, P. V. ZAKHAROV, M. D. STAROSTENKOV, A. S. VDOVIN
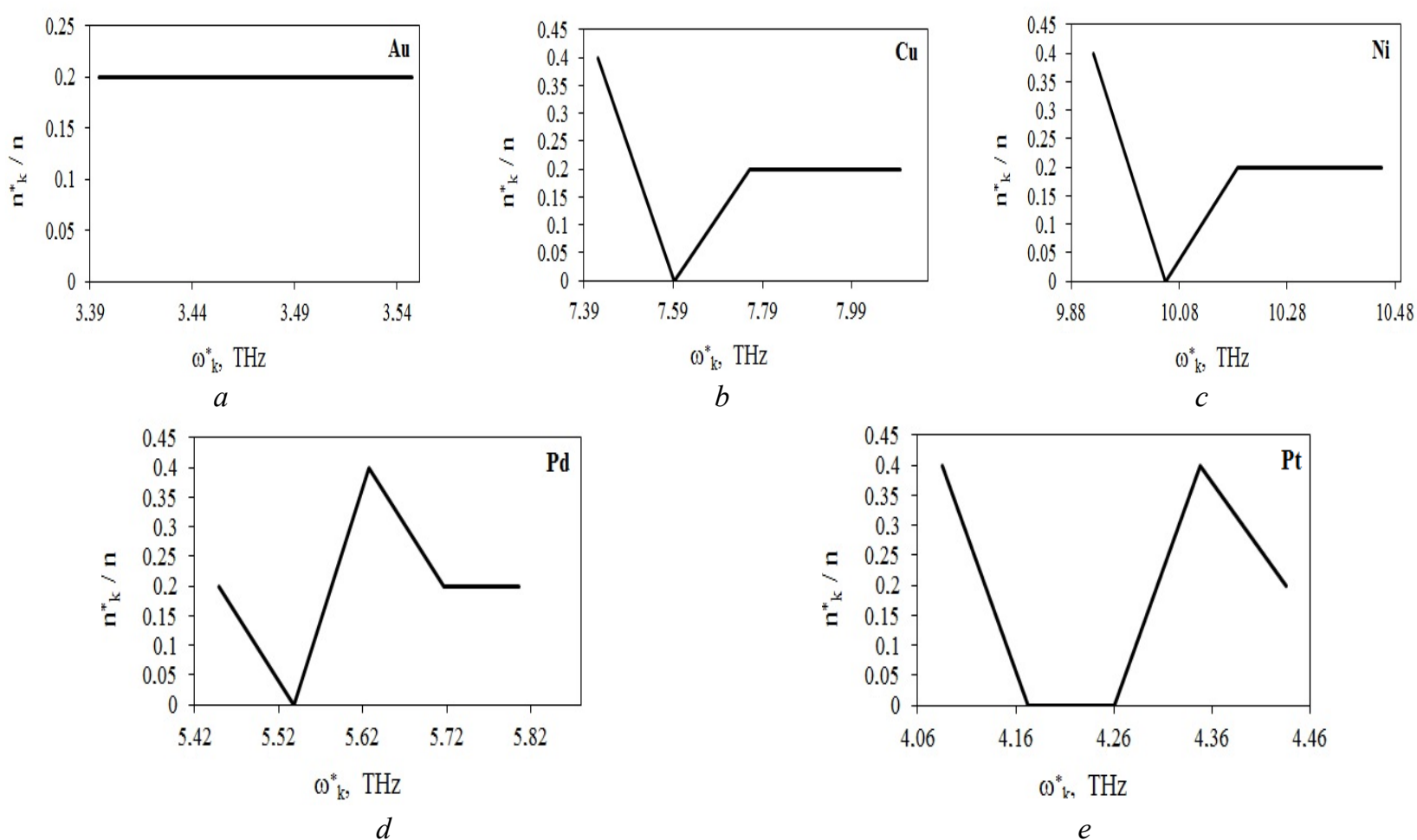

$e$

Fig. 3. Polygons of relative frequencies of discrete breathers: $a-\mathrm{Au}, b-\mathrm{Cu}, c-\mathrm{Ni}, d-\mathrm{Pd}, e-\mathrm{Pt}$
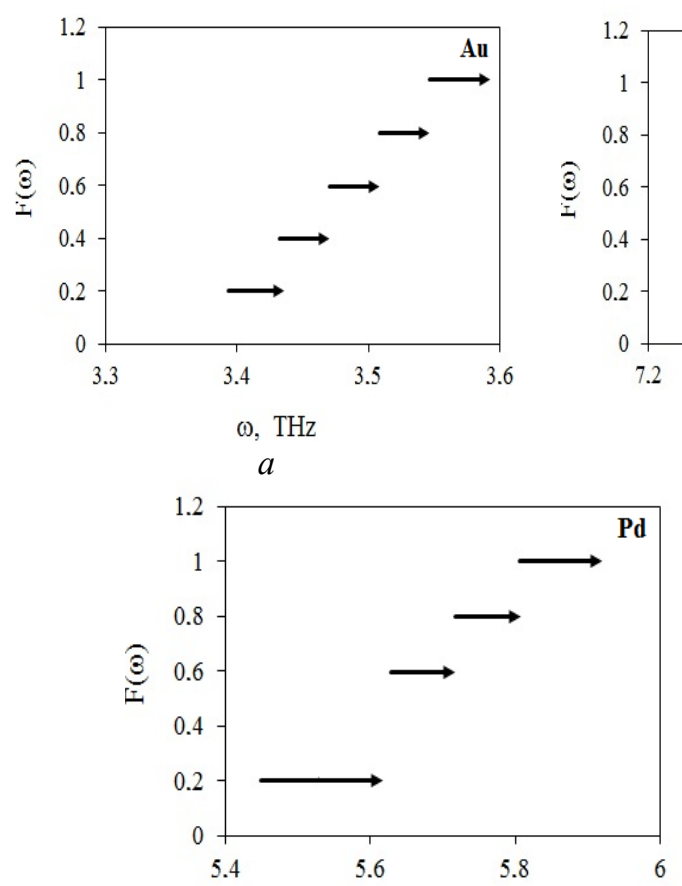

$\omega, \mathrm{THz}$
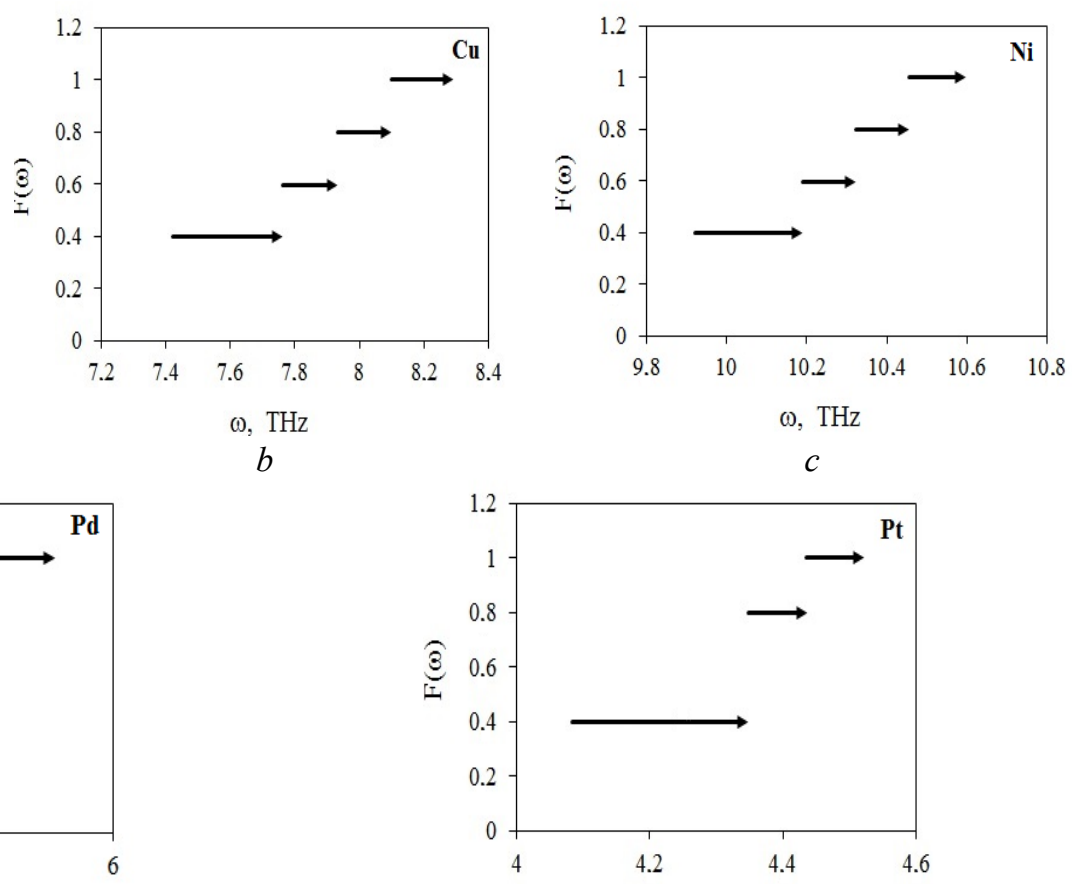

$\omega, \mathrm{THz}$

e

Fig. 4. Empirical distribution functions: $a-\mathrm{Au}, b-\mathrm{Cu}, c-\mathrm{Ni}, d-\mathrm{Pd}, e-\mathrm{Pt}$ 
The obtained statistical data show the process of energy dissipation by breathers on the whole interval of their lifetime. The destruction of quasi-breathers occurs at a time when the root-mean-square deviation exceeds the difference between the average frequency of the breather and the nearest boundary of the phonon spectrum of the crystal. In this case, this process may not be uniform, which is primarily due to the properties of the crystals, as well as the method of exciting the breathers.

\section{CONCLUSION}

In the work of molecular dynamics using the statistical approach, quasi-breathers in monoatomic FCC crystals $\mathrm{Cu}, \mathrm{Au}, \mathrm{Pt}, \mathrm{Ni}$, and $\mathrm{Pd}$ are considered. Dispersion curves and densities of phonon states are calculated for all crystals. All the basic statistical characteristics of quasi-breather frequencies are calculated: the standard deviation of the frequencies of the atoms, the mean frequencies of the quasibreather, the polygons of the relative frequencies, the mathematical expectation, the variance, and the empirical distribution functions. It is established that the root-mean-square deviation of vibration frequencies of quasi-breather atoms, that is, the degree of their quasi-breathing, increases with time (see Fig. 2), and the average frequency of their oscillations decreases, approaching the upper boundary of the phonon spectrum (see Table 1). Quasi-breathers are destroyed when the root-mean-square deviation of the vibration frequencies exceeds the difference between the average frequency of the breather and the nearest boundary of the phonon spectrum of the crystal. The obtained statistical data allow describing the process of degradation of DB with the passage of time. It is important that the described approaches make it possible to establish that quasi-breathers having a shorter lifetime dissipate energy at the initial stages of existence, which is caused both by the method of exciting the breathers and by the properties of model crystals.

\section{ACKNOWLEDGMENTS}

For AME, PVZ, the study was carried out with the financial support of the Russian Federal Property Fund and the Altai Territory within the framework of the scientific project No. 18-42-220002; The MDS is grateful to the Ministry of Education and Science of the basic part of the state task, project No. 3.4820.2017/ $B C$.

\section{REFERENCES}

1. Flach S., Gorbach A. Physics Reports, 2008, vol. 467, pp. 1-116. DOI: https://doi.org/10.1016/j. physrep.2008.05.002

2. Sato M., Sievers A. J. Nature, 2004, vol. 432, pp. 486. DOI: https://doi.org/1038/nature03038

3. Fleischer J. W., Carmon T., Segev M., Efremidis N. K. Christodoulides D. N. Physical Review Letters, 2003, vol. 90, no. 2, pp. 023902. DOI: https://doi.org/10.1103/ PhysRevLett.90.023902

4. Velarde M. G., Chetverikov A. P., Ebeling W., Dmitriev S. V., Lakhno V. D. Proceedings of the Estonian Academy of Sciences, 2015, vol. 64, no. 3, pp. 396-404. DOI: https://doi.org/10.3176/proc.2015.3S.10

5. Dolgov A. S. Physics of the Solid State, 1986, vol. 28, no. 6. pp. 1641-1644.

6. Dmitriev S. V., Khadeeva L. Z. Physics of the Solid State, 2011, vol. 53, no. 7, pp. 1425-1430. DOI: https://doi. org/10.1134/S1063783411070079

7. Medvedev N. N., Starostenkov M. D., Potekaev A. I., Zakharov P. V., Markidonov A. V., Eremin A. M. Russian Physics Journal, 2014, vol. 57, no. 3, pp. 387-395. DOI: https://doi.org/10.1007/s11182-014-0251-5

8. Zaharov P. V., Starostenkov M. D., Eremin A. M., Markidonov A. V. Fundamental'nye problemy sovremennogo materialovedeniya [Basic Problems of Material Science], 2014, vol. 11, no. 2, pp. 260-264.

9. Zaharov P. V., Starostenkov M. D., Medvedev N. N., Eremin A. M., Markidonov A. V. Fundamental'nye problemy sovremennogo materialovedeniya [Basic Problems of Material Science], 2014, vol. 11, no. 3, pp. 388-393.

10. Zakharov P. V., Starostenkov M. D., Dmitriev S. V., Medvedev N. N., Eremin A. M. Journal of Experimental and Theoretical Physics, 2015, vol. 121, no. 2, pp. 217-221. DOI: https://doi.org/10.1134/S1063776115080154

11. Starostenkov M. D., Potekaev A. I., Dmitriev S. V., Zakharov P. V., Eremin A. M., Kulagina V. V. Russian Physics Journal, 2016, vol. 58, no. 9, pp. 1353-1357. DOI: https://doi.org/10.1007/s11182-016-0654-6

12. Zaharov P. V., Eremin A. M., Starostenkov M. D., Markidonov A. V. Komp'yuternye issledovaniya i modelirovanie [Computer Studies and Modeling], 2015, vol. 7, no. 5, pp. 1089-1096.

13. Zakharov P. V., Dmitriev S. V., Starostenkov M. D., Eremin A. M., Korznikova E. A. Journal of Experimental and Theoretical Physics, 2017, vol. 125, no. 5, pp. 913-919. DOI: https://doi.org/10.1134/S1063776117100181

14. Zakharov P. V., Starostenkov M. D., Eremin A. M., Korznikova E. A., Dmitriev S. V. Physics of the Solid State, 2017, vol. 59, no. 2, pp. 223-228. DOI: https://doi. org/10.1134/S1063783417020342

15. Baimova Yu. A., Yamilova A. B., Lobzenko I. P., Dmitriev S. V., Chechin G. M. Fundamental'nye problemy sovremennogo materialovedeniya [Basic Problems of Material Science], 2014, vol. 11, no. 4/2, pp. 599-604. 
16. Chechin G. M., Dzhelauhova G. S., and Mehonoshina E. A. Physical Review E, 2006, vol. 74, pp. 36608. DOI: https://doi.org/10.1103/PhysRevE.74.036608

17. LAMMPS Molecular Dynamics Simulator. URL: http://lammps.sandia.gov/ (Date of circulation: June 14, 2018).

18. Zhou X. W., Johnson R. A., and Wadley H. N. G. Physical Review B, 2004, vol. 69, pp. 144113. DOI: https:// doi.org/10.1103/PhysRevB.69.144113
19. Zakharov P. V., Starostenkov M. D., Dmitriev S. V., Eremin A. M., Cherednichenko A. I. Letters on Materials, 2016, vol. 6, no. 4, pp. 294-299. DOI: https://doi. org/10.22226/2410-3535-2016-4-294-299

20. Eremin A. M., Zaharov P. V., Starostenkov M. D. Himicheskaya fizika i mezoskopiya [Chemical Physics and Mesoscopy], 2016, vol. 18, no. 4, pp. 565-573.

21. Zakharov P. V., Eremin A. M., Starostenkov M. D., Lucenko I. S. Key Engineering Materials, 2017, vol. 743, pp. 86-90. DOI: https://doi.org/10.4028/www.scientific. net/kem.743.86

УДК 538.913

\title{
АНАЛИЗ СТАТИСТИЧЕСКИХ ХАРАКТЕРИСТИК КВАЗИ-БРИЗЕРОВ В МОНОАТОМНЫХ ГЦК МЕТАЛЛАХ Аu, Cu, Ni, Pd И Pt
}

\author{
(ㄱ) 2018 А. М. Ерёмин ${ }^{1}$, П. В. Захаров ${ }^{1}$, М. Д. Старостенков ${ }^{2}$, А. С. Вдовин ${ }^{1}$ \\ ${ }^{1}$ Алтайский государственный гуманитарно-педагогический университет им. В.М. Шукиина, \\ ул. Короленко, 53, 659333 Алтайский край, Бийск, Россия \\ ${ }^{2}$ Алтайский государственный технический университет им. И.И. Ползунова, \\ пр. Ленина, 46, 656038 Алтайский край, Барнаул, Россия \\ e-mail:eam77@yandex.ru
}

Поступила в редакцию 08.08.2018

\begin{abstract}
Аннотация. Методом молекулярной динамики проводится расчёт и анализ статистических характеристик квази-бризера с жёстким типом нелинейности в моноатомных ГЦК металлах, на примере $\mathrm{Cu}$, $\mathrm{Au}, \mathrm{Pt}$. Ni и Pd. B рамках данной модели для квази-бризеров были рассчитаны следующие статистические характеристики и зависимости: группированный статистический ряд абсолютных и относительных частот, полигон абсолютных и относительных частот, гистограмма относительных частот, эмпирическая функция распределения, оценка математического ожидания и дисперсии исходной выборки. Для всех кристаллов рассчитаны плотности фононных состояний. Статистические данные позволяют вникнуть в причины разрушения бризеров и более полно описать процесс рассеяния ими энергии.
\end{abstract}

Ключевые слова: кристалл, квази-бризер, дискретный бризер, нелинейная динамика, солитон, молекулярная динамика.

DOI: https://doi.org/10.17308/kcmf.2018.20/628

Для АМЕ, ПВЗ исследование выполнено при финансовой поддержке РФФИ и Алтайского края в рамках научного проекта № 18-42-220002 p_a;

МДС выражает благодарность Министерствуобразования и науки, базовой части государственного задания, проект № 3.4820.2017/БЧ.

Ерёмин Александр Михайлович - к. ф.-м. н., доцент, доцент кафедры математики, физики, информатики, Алтайский государственный гуманитарно-педагогический университет им. В. М. Шукшина, Бийск, Россия; тел.: +7 (3854) 337438, e-mail: eam77@yandex.ru
Alexander M. Eremin - Cand. Sci. (Phys.-Math.), Associate Professor, Shukshin Altai State Humanities Pedagogical University, Biysk, Russia; tel.: + 7 (3854) 337438, e-mail: eam77@yandex.ru 
Захаров Павел Васильевич - к. ф.-м. н., доцент, доцент кафедры математики, физики, информатики, Алтайский государственный гуманитарнопедагогический университет им. В. М. Шукшина, Бийск, Россия; тел.: +7 (3854) 337438, e-mail: zakharovpvl@rambler.ru

Старостенков Михаил Дмитриевич - д. ф.-м. н., профессор, заведующий кафедрой физики, Алтайский государственный технический университет им. И. И. Ползунова, Барнаул, Россия, тел.: +7 (3852) 290852, e-mail: genphys@mail.ru

Вдовин Алексей Сергеевич - старший преподаватель кафедры математики, физики, информатики, Алтайский государственный гуманитарнопедагогический университет им. В. М. Шукшина, Бийск, Россия; тел.: +7 (3854) 337438, e-mail: ronin_78@mail.ru
Pavel V. Zakharov - Cand. Sci. (Phys.-Math.), Associate Professor, Shukshin Altai State Humanities Pedagogical University, Biysk, Russia; tel.: +7 (3854) 337438, e-mail: zakharovpvl@rambler.ru

Mikhail D. Starostenkov - Dr. Sci. (Phys.-Math.), Full Professor, Head of the Department of Physics, Polzunov Altai State Technical University, Barnaul, Russia; tel.: +7 (3852) 290852, e-mail: genphys@ mail.ru

Alexey S. Vdovin - Senior Lecturer, Shukshin Altai State Humanities Pedagogical University, Biysk, Russia; tel.: +7 (3854) 337438, e-mail: ronin_78@ mail.ru 